Tyndale Bulletin 70.2 (2019) 291-316

\title{
LUTHER, HEIDEGGER, AND THE HIDDENNESS OF GOD
}

\author{
Mark Norman \\ (marnorman@hotmail.com)
}

\begin{abstract}
Summary
This paper seeks to trace how certain Lutheran themes, particularly the tendency towards fideism evidenced in the Lutheran 'Deus absconditus' ('hidden God'), were later adopted by Heidegger, and then misappropriated by certain 'post-theological' thinkers of the continental tradition in the late twentieth century. In what follows, the early Luther and his theology of the Cross will be firstly placed into its late medieval nominalist context, after which Heidegger's employment of the Lutheran 'hidden God' in his formulation of the question of 'being' will be discussed. Finally, I will propose that the appreciation of Luther's legacy and his relevance for philosophy lies not in popular 'Heideggerian' revisionist readings of the reformer but, alternatively, through integrating the Deus absconditus theme into the rest of his theological thought, including his historical context. ${ }^{1}$
\end{abstract}

\section{Introduction: Luther and Heidegger}

'Nature/being likes to hide ...' - Heraclitus ${ }^{2}$

1 The post-metaphysical French thinkers are of particular relevance due to their influence on Continental thought worldwide. For Heidegger's own influence, see D. Janicaud, Heidegger in France, trans. F. Raffoul and D. Pettigrew (Bloomington: Indiana Press, 2015). For a study of this relatively recent development in France since the 1980s resulting in a greater role for religion in the public square, see E. McCaffrey, The Return of Religion in France: From Democratisation to Postmetaphysics (New York: Palgrave Macmillan, 2009): 1ff.

2 Heraclitus, Fragment DK 123. In C. Kahn, The Art and Thought of Heraclitus: A New Arrangement and Translation of the Fragments with Literary and Philosophical Commentary (Oxford: Oxford University Press, 2008): 32. For Heidegger's idiosyncratic translation of Heraclitus' use of 'phusis', see C. J. White, Heidegger and 
For the word of the cross is folly to those who are perishing, but to us who are being saved it is the power of God. -1 Corinthians 1:18

Luther's notion of the theologia crucis together with that of the hiddenness of God came to fruition in his thought after an extended and prayerful reflection on the Scriptures. ${ }^{3}$ Whilst orthodox late medieval theology had always acknowledged God's transcendence, Luther's doctrine of divine hiddenness was partly employed to combat medieval theology's somewhat overconfident synthesis between faith and reason. This Lutheran theme would later attract the early Heidegger, who at the beginning of the twentieth century also sought a basis on which to 'destroy' Western philosophy. ${ }^{4}$

However, for various reasons, Luther (1483-1546) and Heidegger (1889-1976) remain antithetical figures. The reformer was a product of the late middle ages, whereas Heidegger, as a lapsed Christian and atheist, lived in the twentieth century. Yet, interestingly, Luther and Heidegger also shared certain priorities. From German peasant stock, each experienced tumultuous times of socio-political change. Although initially steeped in medieval scholasticism, each became antagonistic of ecclesiastical metaphysics. They also called for a renewal, even a 'destruction', of philosophy, whilst advocating a 'conversion' to a more primordial spiritual reality. ${ }^{5}$ Also, their writings reflect antisemitic tendencies. ${ }^{6}$ We additionally detect a mutual regard for the 'experiential' life of faith in the face of mystery, whether the inscrutability of the Deus absconditus, or, Heidegger's case, the 'call of being'. Metaphysically, their dualistic approaches remained paradoxical, embracing contradictory poles, whether faith versus

the Greeks in H. L. Dreyfus et al., eds, A Companion to Heidegger (Oxford: Blackwell, 2007): 129.

3 Here we think specifically of Luther's study of the Psalms and the Letter to the Romans. See A. E. McGrath, Luther's Theology of the Cross: Martin Luther's Theological Breakthrough (Oxford: Blackwell, 2011): 127-35.

4 D. Armitage, Heidegger's Pauline and Lutheran Roots (Basingstoke: Palgrave Macmillan, 2016): 4-6.

5 For the young Heidegger's Christian background, see S. J. McGrath, The Early Heidegger and Medieval Philosophy: Phenomenology for the Godforsaken (Washington: Catholic University of America Press, 2006) $1 \mathrm{ff}$.

6 For antisemitism in Heidegger, see for example V. Farias, Heidegger and Nazism, trans. J. Margolis (Philadelphia: Temple University Press, 1989); E. Faye, Heidegger: The Introduction of Nazism into Philosophy, trans. M. B. Smith (New Haven: Yale University Press, 2009). For Luther's antisemitism, see the latest study: T. Kaufmann, Luther's Jews, trans. L. Sharpe and J. M. Noakes (Oxford: Oxford University Press, 2017). 
reason, or, with Heidegger, the ontological difference between Being and beings.

\section{Luther and Scholasticism}

Methodologically speaking, originating with Boethius, Anselm, and then Abelard, we can define 'scholasticism' broadly as embracing a diverse range of opinions but climaxing specifically with Aquinas and his successors' attempts to synthesise Aristotle and Christian theology from the $1200 \mathrm{~s}^{7}$ Based on the twofold authority of divine revelation as interpreted by the magisterium and reason, Aquinas' scholasticism regards revelation as ultimately beyond intellectual grasp, but at the same time not necessarily in contradiction to it. ${ }^{8}$ Employing the syllogism and the dialectical method, reason explicates revelation through the reconciliation of potential conceptual opposites, whilst attending to objections. ${ }^{9}$

\section{Nominalism}

After Aquinas, one of the progenitors of later medieval nominalism was the Franciscan William of Ockham (c. 1285-1349), followed by Gabriel Biel and others. ${ }^{10}$ With the earlier thought of Scotus and then Ockham and Biel, the Thomist synthesis came under threat due to the partial rejection of realism. Nominalism placed new weight on the

7 McGrath, The Early Heidegger, 4. The term 'scholasticism' is a relatively recent one. See U. G. Leinsle, Introduction to Scholastic Theology, trans. M. J. Miller (Washington: Catholic University of America Press, 2010): 3ff. Scholasticism, however, hardly ends with Aquinas, as both Scotus and Ockham were also scholastic figures. J. Marenbon, Medieval Philosophy: An Historical and Philosophical Introduction (London: Routledge, 2007): 205-23. Scholastic elements are also present in contemporary neo-Thomism.

8 T. Aquinas, Summa Theologica, trans. Fathers of the English Dominican Province (London: Sheed \& Ward, 1981), Vol. I, Q1. Art 8: 6: 'Since therefore grace does not destroy nature, but perfects it, natural reason should minister to faith as the natural bent of the will ministers to charity.' Of course, later, with the thought of Scotus and then particularly Ockham, this synthesis would increasingly come under pressure.

9 G. Ebeling, Luther: An Introduction to his Thought (Minneapolis: Fortress, 1970): 83; A. Vos, The Philosophy of John Duns Scotus (Edinburgh: Edinburgh University Press, 2006): 223.

10 See W. Ockham, Opera Philosophica et Theologica: Opera Theologica (New York: St. Bonaventure University, 1967), Vol I. Scriptum in librum primum Sententiarum. Ordinato. Prologus et Distinctio Prima: 1967ff. 
omnipotent will of God or the potentia absoluta as opposed to the potentia ordinata. ${ }^{11}$ Ockham's interest in preserving the creator's absolute volition led to tensions between the transcendent versus the immanent deity whose works are amenable to human understanding. This is because, in theory, an omnipotent creator could have created a cosmos contrary to its current moral order or his ordained will (potentia ordinata). ${ }^{12}$ With Ockham's voluntarism, in theory, God can create anything which, whilst not involving contradiction, nevertheless still transcends reason. ${ }^{13}$ This is contrary to Thomas and the via antiqua. With via antiqua, the assumption was that when God exercises his volition he does so according to the confines of reason and revelation. Ockham's alternative was one of the factors which would result in the death knell of Aquinas' synthesis.

Nominalism also brought the Aristotelian principle of causality into question. This presupposition lay at the heart of Aquinas' Summa and his theology of creation. Alternatively, however, if we conclude there are no rational essences inherent in entities, enabling them to relate to others, the causal links of the scholastic universe falter as the creator can no longer be perceived as being connected to the cosmos through

11 Here reference is made to God's absolute will versus his ordained will. Dieter points out that this distinction predates Ockham, but in his own theology it plays an increasingly important role. See T. Dieter, 'Luther as a Late Medieval Theologian: His Positive and Negative use of Nominalism and Realism' in R. Kolb et al., eds, The Oxford Handbook of Martin Luther's Theology (Oxford: Oxford University Press, 2014): 32-34. See also the study by W. J. Courtenay, Capacity and Volition: A History of the Distinction between Absolute and Ordained Power. Quodlibet 8 (Bergamo: Pierluigi Lubrina Editore, 1990).

12 G. Leff, William of Ockham: The Metamorphosis of Scholastic Discourse (Manchester: Rowman \& Littlefield/Manchester University Press, 1975): 525; Leinsle, Introduction to Scholastic Theology, 225. Whilst Ockham does not reject the importance of the potentita ordinate, nevertheless, God could in theory have brought about the existence of contingent things without secondary causes. Furthermore, if he so chose, he could have ordained to justify or save individuals without their possessing the requisite prior disposition. A. E. McGrath, Iustitia Dei. A History of the Christian Doctrine of Justification (Cambridge: Cambridge University Press, 2005): 182-83. McGrath states (Iustitia Dei, 182), 'The criterion of merit or demerit is what God chooses to accept or reject, lying outside the moral agent, and not reflecting any quality (such as a created habit) inherent in the viator.'

13 M. M. Adams, William Ockham (Vol II; Notre Dame: University of Notre Dame, 1987): 1155. Aquinas, in comparison, placed far more restrictions on God's omnipotent freedom. For example, God cannot get drunk as people can. B. Davies, The Thought of Thomas Aquinas (Oxford: Oxford University Press, 2009): 122-23. See also Aquinas, Summa Theologica, Vol. I. Q. 25. Art. 4-6: 139-41. 
intellectually accessible causes. ${ }^{14}$ Anticipating the future intellectual revolution of the Enlightenment (and the thought of Hume), nominalist assumptions would result in the separation between theology and philosophy as disciplines. These assumptions, together with the weight placed on God's omnipotence, also somewhat anticipated Luther's theology of the Cross versus what he regarded as 'theologies of glory'.

Of related significance is Ockham's rejection of the realist view of universals as existing outside the mind. Nominalism insisted that universal concepts are mere termini in grammatical propositions. They are not located in nature. Thus, only individual entities exist outside the mind. ${ }^{15}$ This individualism spearheaded a novel, empirical approach to knowledge and the reduction of the scope of natural theology. ${ }^{16}$ Faithwise, it also allowed for a greater appreciation of the importance of the individual's experience of God in the quest for assurance, and this was also to influence Luther. ${ }^{17}$ Even the early Heidegger found inspiration for his formulation of the hermeneutics of the 'factical' life of the individual from his own reading of Scotus and the via moderna. ${ }^{18}$ Here we also encounter the origins of existential philosophy.

Ockham's privileging of the potentia absoluta resulted in the propensity to separate faith from reason (this separation viewed in a conative and not absolute sense). ${ }^{19}$ This was to impact Luther, trained

14 H. O. Oberman, 'Via Antiqua and Via Moderna: Late Medieval Prolegomena to Early Reformation Thought', Journal of the History of Ideas 48.1 (1987): 28.

15 W. Ockham, Quodlibeta. I. Q. XIII in P. Boehner, Ockham: Philosophical Writings, trans. P. Boehner (Indianapolis: Bobs-Merrill; The Library of Liberal Arts, 1964): 31. Here, Ockham rejects Aquinas' Aristotelianism. He writes 'That no universal is a substance existing outside the mind can be proved in a number of ways ...' W. Ockham, Ockham's Theory of Terms: Part 1 of the Summa Logicae, trans. M. J. Loux (Notre Dame: University of Notre Dame Press, 1974): 79.

16 Adams, William Ockham, Vol. II, 979. See also Ockham, Quodlibeta, V.Q.1, 109ff.

17 H.-M. Barth, The Theology of Martin Luther: A Critical Assessment, (Minneapolis: Fortress, 2012): 24.

18 Heidegger completed his Habilitationsschrift (originally attributed to Duns Scotus), 'The Doctrine of Categories and of Meaning of Duns Scotus', on Thomas of Erfurt, a thirteenth-century Scotist. See J. Caputo, 'Phenomenology, Mysticism and the "Gramatica Speculativa": A Study of Heidegger's "Habilitationsschrift", Journal of the British Society of Phenomenology 5.2 (1974): 101. Heidegger's habilitation is published in M. Heidegger, 'Duns Scotus' Doctrine of Categories and Meaning' in J. Van Buren, ed., Supplements: From the Earliest Essays to Being and Time and Beyond (New York: State University of New York Press, 2002).

19 Adams, William Ockham, Vol. II, 1187; A. J. Freddoso, 'Ockham on Faith and Reason' in V. Spade, ed., The Cambridge Companion to Ockham (Cambridge: Cambridge University Press, 1999): 328. While this distinction does not originate with 
according to the via moderna. Certainly, from the patristic period, the church baptised Greek thought in the formulation of doctrine, but this usage was always circumspect, subject to the Augustinian principle of credo ut intelligam. Nevertheless, by the age of Thomas (partly due to the recent availability of further Aristotelian texts from the East), unprecedented confidence was placed in the importance of philosophy in the articulation of theological truth, enabling theology to be viewed as a science. ${ }^{20}$ Nonetheless, anticipating Luther's own reservations, as we have seen, the proponents of the via moderna were ambivalent when it came to philosophy as a tool in the establishment of systematic theology. ${ }^{21}$

\section{The Univocity of Being}

Luther's insistence on the infinite qualitative distinction between humanity and God was partly due to his rejection of the notion of the univocity of being, originally advocated by Scotus, and then Ockham. Ockham upheld univocity as an alternative to the analogia entis of the via antiqua. ${ }^{22}$ Scotus jettisoned the Thomist view that the immediate, most suitable object of the intellect is the essence (quiddity) of the material object. He also discarded Henry of Ghent's Augustinian alternative in which the principal object of the intellect was deemed to be God or 'being' as made available to the human cognition. ${ }^{23}$ With Scotus, the intellect's primary object was reconceived as 'being', albeit in a somewhat idealistic sense. Here, 'being' is conceived as univocal, prior to all human experience of any specific entity, including God

Ockham, the stress on God's absolute power and will reflects a new development in Scholastic theology.

20 Aquinas, Summa Theologica, Vol. I. Q. 1. Art. 1: 1: 'Whether Sacred Doctrine is a Science', Q. 1. Art 3: 'Whether Sacred Doctrine is One Science: 2-3.

21 B. Gaybba, Aspects of the Medieval History of Theology (Pretoria: University of South Africa, 1988): 264.

22 Marenbon, Medieval Philosophy, 282-83; Vos, The Philosophy of John Duns Scotus, 285-88. Of course, Scotus was not the first individual to imply such univocity. Although Aristotle speaks of being as occurring in 'many ways', the fact that all of being can be studied conceptually implies 'univocity' as well. The principle has its originator with Parmenides, who argued that all which 'is' is part of 'being' whereas that which is 'not' cannot be part of being. See D. W. Graham, ed., The Texts of Early Greek Philosophy (Cambridge: Cambridge University Press, 2010): 215-17.

23 Following E. Bettoni, Duns Scotus: The Basic Principles of his Philosophy, trans. B. Bernadine (Connecticut: Greenwood Press, 1979): 27-35. 
himself. As the intellect's primary intentional object, 'being' thus functions on a 'pre-experiential' level, enabling the intellect to grasp hold of entities and to develop abstract knowledge. Being allows beings and, indeed, all knowledge to 'show up' in the mind. Here we can locate one of the roots of Heidegger's ontological difference between being and beings. ${ }^{24}$ Now if all knowledge (including knowledge of finite and infinite beings) depends on a singular, allencompassing, pre-theoretical notion of 'being', we must as a consequence reject the Thomist dictum of the analogia entis, as being must be univocal in its make-up. Luther's (and Barth's) difficulty with this lay in the fact that, notwithstanding Ockham's distinction between infinite and finite being as a means of preserving divine transcendence, univocity leads to the domestication of the divine being.

\section{Luther's Criticism of Aristotle and Scholasticism in Context}

As a late medieval thinker, Luther needs to be placed into his intellectual context, as both before and after his evangelical breakthrough he remained indebted to the intellectual currents of his time. ${ }^{25}$ Yet he was critical of the Thomists and the nominalists of the fourteenth century. ${ }^{26}$

Scholasticism's view of being was largely Aristotelian, even if by the thirteenth century being had been amplified beyond Aristotle's categories to include angels and other metaphysical doctrines such as unity and goodness. ${ }^{27}$

24 McGrath, The Early Heidegger, 98-99.

25 While Luther referred to Scotus as his 'teacher', in terms of the via moderna, he was also influenced by the thought of Gabriel Biel, who was also popular at Erfurt.

26 Leinsle, Introduction to Scholastic Theology, 3. Luther states, 'Feed my sheep! This means: bring out that by which they are fed. And they are fed only by the Word of God, not by the opinions and traditions of men. In addition what you so truly said that no argument is so keen that it cannot be refuted - is abundantly substantiated by the miserable treadmill in which the Scotists, Thomists, Albertists, modernists, and all the sects into which these are subdivided waste their time.' M. Luther, 'Selected Psalms III' in J. Pelikan, ed., Luther's Works (Vol. 14; Saint Louis: Concordia Publishing House, 1958): 284.

27 Marenbon, Medieval Philosophy, 284. Scotus would include the distinction of 'infinite' or 'finite' being in the transcendentals. When we consider being, we firstly consider the infinite God, or, on the other hand, the finite being of created things; the latter divides into the Aristotelian ten categories. 
Luther's criticisms of Aristotle as well as of scholasticism are well known. ${ }^{28}$ In his 'Disputation Against Scholastic Theology', the reformer goes as far as suggesting that one would be a better off as a theologian without Aristotle. ${ }^{29}$ Aristotle is as 'darkness compared to light'. ${ }^{30}$ However, we should not conclude that Luther rejected philosophy out of hand, as he also acknowledged his debt to Aristotle, being convinced that, as a strict handmaiden to theology and God's revelation, Aristotelianism could still in fact play a helpful role in the articulation of biblical truth. ${ }^{31}$ Rather, his reservations focused on what he viewed as the illegitimate importation of Aristotelian categories into theology and biblical exegesis. ${ }^{32}$ Over-reliance on Aristotelianism masked the true majesty and power of the God of Scripture. ${ }^{33}$ Parallel to his belief in the incommensurability between law and Gospel, Luther also insisted that pagan philosophy is inadequate when it comes to comprehending the paradoxical reality of the infinite entering into the

28 For Luther's knowledge of Aristotle, see T. Dieter, Der Junge Luther und Aristoteles. Historisch-systematische Untersuchungen zum Verhältnis von Theologie und Philosophie (Berlin and New York: De Gruyter, 2000). Luther's criticisms of Aquinas as the representative of the via antiqua appear fairly frequently, despite his limited first-hand reading of Thomas. R. Kolb, Martin Luther: Confessor of the Faith (Oxford: Oxford University Press, 2009): 31, 34. In this regard, see also D. Janz, Luther on Thomas Aquinas: The Angelic Doctor in the Thought of the Reformer (Stuttgart: Franz Steiner Verlag, 1989); also D. Janz, Luther and Late Medieval Thomism (Waterloo, Ontario: Wilfred Laurier University Press, 2009).

29 See Luther's Disputation Against Scholastic Theology, Thesis 43-44. '43. It is an error to say that no man can become a theologian without Aristotle. This in opposition to common opinion. 44. Indeed, no one can become a theologian unless he becomes one without Aristotle.' M. Luther, 'Disputation Against Scholastic Theology' in T. Lull, Martin Luther's Basic Theological Writings (Minneapolis: Augsburg University Press, 1989): 16.

30 'Briefly, the whole of AristotIe is to theology as darkness is to light.' Luther, 'Disputation Against Scholastic Theology', Thesis 50: 16.

31 Kolb, Martin Luther, 30. Writes Saak, 'Within the realm of the external word, Luther could claim that Aristotle's philosophy was beautiful and useful for the highest theology. The emphasis here must be on the concept of usefulness and usefulness in the context of instruction. This is also the proper context for understanding Luther's use of the first figure syllogism for illustrating the relationship between the divine essence and the divine persons.' L. Saak, Luther and the Reformation of the Later Middle Ages (Cambridge: Cambridge University Press, 2017): 150.

32 In the Dispute against Scholastic Theology he states in Thesis 51 'It is very doubtful whether the Latins comprehended the correct meaning of Aristotle.' Luther, 'Disputation Against Scholastic Theology', 16. The reformer, however, was still positive about the use of Aristotle in the realm physics, for example.

33 Kolb, Martin Luther, 34. 
finite. ${ }^{34}$ Aristotle's metaphysics might assist us in apprehending the world (coram mundo), but it fails to plumb the truths of the incarnation and our knowledge of God (coram deo). ${ }^{35}$ In regard to the latter, the scholastic method of the via antiqua as well as that of the via moderna, including the debate on the distinction between the univocal versus the equivocal understanding of being, is inadequate. ${ }^{36}$ Alternatively, what is required is an new theological language (nova lingua) which allows us to give justice to the gospel, as the truths of philosophy are not necessarily those of theology.

\section{Luther, Philosophy, and 'Being'}

Of course, Luther acknowledged that when discussing God as theologians, we inevitably have no choice but to employ some form of 'common human language' (lingua franca), whether we are discussing God's revelation or whether we are engaging with profane ideas in general. But how is language actually employed in each particular case, i.e., language in the service of revelation as opposed to its more 'mundane', everyday use? In each instance, is language used in precisely the same manner?

In attending to this question in Luther, Luy proposes two possibilities: first, discontinuity of displacement, and, second,

34 D. Bielfeldt, 'Luther and Ontology' in Oxford Research Encyclopaedia of Religion (religion.oxfordre.com/view/10.1093/acrefore/.../acrefore-9780199340378-e-351). See also D. Tracy, 'Martin Luther's Deus Theologicus' in P. J. Malysz and D. R. Nelson, eds, Luther Refracted (Minneapolis: Augsburg, 2015): 109. Luther states 'For although the power of God is infinite, still, according to philosophy God cannot be spoken of as both Creator and creature, as God and man. It is true that philosophy acknowledges God exists and that he is omnipotent; nevertheless, it is in no way possible to acknowledge on the basis of philosophy that he can become man, because God himself is infinite. For if he is of infinite power, he cannot become finite man because man is part of the finite.' M. Luther, 'The Disputation Concerning the Passage: "The Word Was Flesh" (John 1:14)' (1539) in M. E. Lehmann, ed. Luther's Works (Vol. 38; Saint Louis: Concordia Press, 1971): 245.

35 Bielfeldt, Luther and Ontology.

36 'truth is not identical in theology and in philosophy'. Luther, 'The Disputation Concerning the Passage: "The Word Was Flesh"', 247. He also states: 'And they devised the distinction between equivocal and univocal so that philosophy might be in harmony with theology. So we say the Parisians have erred in this ... it is therefore remarkable that that they have concluded that a word is identical in theology and philosophy.' Luther, 'The Disputation Concerning the Passage: "The Word Was Flesh”, 246, Tracy, 'Martin Luther's Deus Theologicus', 109. 
discontinuity of depth. ${ }^{37}$ With the first option, discontinuity of displacement, the distinction drawn is radical, even on a fundamental, ontological level. Here, philosophical and theological language might use similar words, but they describe totally different realities. However, with the second alternative of the discontinuity of depth, the distinction between the languages of theology and philosophy points not so much to two totally contrary ontological realities; rather theology is regarded as delving deeper into the description of its unique subject when compared to philosophy. ${ }^{38}$ In our view, the second option most appropriately fits Luther's language. In other words, the strong transcendent factor in Luther's theology did not result in him abandoning the language of 'being' altogether.

Instead of abandoning the metaphysical view of being, Luther reworked it according to a biblical framework. ${ }^{39}$ All 'being' originates in God's creative purposes and is 'good', meaning that the Platonic notion of multiple 'grades' of being from God's perfection at the metaphysical apex but then lessening in 'goodness' and power as we work our way downwards is rejected. For Luther, God's unique being cannot be compared to that of the creation. Consequently, any attempt to employ the univocal model as a means of explaining a sense of a 'continuum' between God's being and that of the world must be abandoned, as this relationship can only be considered from the perspective of a profound paradox, beyond philosophical language. As such, theology alone can appropriately attend to this paradox as Christ's incarnation bridges the metaphysical realms of divinity and creation. This, however, can only be perceived by faith. ${ }^{40}$ Metaphysically speaking, faith is all important for Luther; subsequently, even the neoplatonist quest to achieve unity with God

37 D. Luy, 'Martin Luther's Disputations', Oxford Research Encyclopedia of Religion (religion@oxfordre.com, online March 2017, accessed 21 June 2017). See also G. White, Luther as Nominalist: A Study of the Logical Methods used in Martin Luther's Disputations in the Light of their Medieval Background (Helsinki: Luther-AgricolaSociety, 1994).

38 Luy, 'Martin Luther's Disputations'. Luy states 'Philosophical and theological terms both describe and refer to the same objects. The difference consists rather at the level of determining the valid inferences, which those terms allow.'

39 M. Mattes, 'Luther's Use of Philosophy'. Paper delivered at Luther as Teacher and Reformer of the University: 12th International Congress for Luther Research, 2012 (wmltblog.org/2012/08/luther-congress-luthers-use-of-philosophy): 111-13, 125-26.

40 M. A. Gillespie, The Theological Origins of Modernity (Chicago: Chicago University Press, 2008): 113-15. 
through 'mystical participation' in the divine being must be replaced by the faith principle.

For Aristotelianism, the notion of 'substance' serves as the central ontological construct, and this is identified by its inner, rational 'essence' and its capacity to subsist through change. ${ }^{41}$ Luther, however, regards 'substantiality' in a more biblically informed sense: individual things are defined by their external relations to other entities, their place in the creation, and, of course, in relation to God. ${ }^{42}$ Additionally, created beings and redeemed humanity itself are defined by their temporal directedness towards their eschatological future in the new creation, not so much by their perpetual presence in this world. It is clear Luther offers a decidedly theological, even Christological, reading of Greek metaphysics. ${ }^{43}$

\section{The 'Deus absconditus' and the Theology of the Cross}

Kolb points out that Luther's breakthrough to his mature evangelical position occurred in stages, over time, and these included significant

41 In Metaphysics Book Delta, Aristotle regards metaphysics as the science of 'being qua being' (introduced in Book Gamma). Metaphysics can be regarded as 'primary philosophy,' 'wisdom', and 'theology'. See J. Barnes, 'Metaphysics' in J. Barnes, ed., The Cambridge Companion to Aristotle (Cambridge: Cambridge University Press, 1995): 66. The study of being does not concern itself with a specific type of knowledge respecting one form of reality; it is a truly universal science in that it seeks to understand the nature of all things, all there is. Barnes, 'Metaphysics', 68; also J. L. Ackrill, Aristotle the Philosopher (Oxford: Oxford University Press, 1981): 116. However, ontologically speaking, substances are the most important independently existing entities, and being is most concerned with these as primary. Ackrill, Aristotle the Philosopher, 118. See also Aristotle, Metaphysics. Book Gamma IV.1: 1022ff in J. Barnes, ed., The Complete Works of Aristotle (Princeton, New Jersey: Princeton University Press, 1984): 1584-85.

42 G. Ebeling, Luther: An Introduction to his Thought (Minneapolis: Fortress, 1970): $87-88$

43 Luther states: 'non-being is a thing without a name and a person in sin; becoming is justification; being is righteousness; work is acting and living justly; passion is to be made perfect and complete ... through this new birth one moves from sin to righteousness, and thus from non-being, through becoming to being ... human being is always in privation, always in becoming or in potentiality, in matter, and always in action. Aristotle philosophizes about such matters, and he does it well, but he is not understood in this sense ...' Luther here is quoted by J. Van Buren, The Young Heidegger. Rumour of the Hidden King (Indianapolis: Indiana University Press, 1994): 200. The quote is taken from Luther's lecture on Romans: M. Luther, 'Lectures on Romans' in H. C. Oswald, ed., Luther's Works (vol. 25; Saint Louis: Concordia Publishing House, 1972): 433-35. 
events (such as the 'Tower Experience' of 1515). ${ }^{44}$ The principal themes of his 'theology of the Cross' were already laid out by 1518 in the Heidelberg Disputation. Here we locate the key expression: 'destruction by the Cross', or 'per crucem destruuntur' ${ }^{45}$ Evidentially, by this point, Luther's reforming impulse had moved him beyond the views of Erasmus and others. ${ }^{46}$

Luther's theology of the Cross appeared partly in response to scholasticism's endorsement of active righteousness, and his subsequent search for personal salvation led to his embracing justification by faith and God's passive righteousness. ${ }^{47}$ The reformer's new view regarding the priority of faith also resulted in him shifting his focus from the medieval emphasis on intellectual assent to dogma to personal trust in Christ and his Cross. ${ }^{48}$ The Cross for Luther is an essential event of faith. ${ }^{49}$

In this regard, a significant Lutheran text (in McGrath's corrected translation) is the 19th Thesis of the Heidelberg Disputation:

Anyone who observes the invisible things of God, understood through those things that are created, does not deserve to be called a theologian..$^{50}$

Prior to his discovery of the gift of God's passive righteousness, Luther's concern for his soul in the face of an angry, distant, and omnipotent Deity (Deus nudus) is evidence of the influence of the via moderna. ${ }^{51}$ In the case of the Ockhamist framework, guarantees of receiving God's grace were somewhat remote. In the face of this dilemma, early in Luther's career, Staupitz urged the reformer not to focus on a distant judge but rather to look to the Cross of Jesus for assurance. ${ }^{52}$ According to Luther's own account of his spiritual

44 Kolb, Martin Luther, 42.

45 M. T. Mjaaland, The Hidden God: Luther, Philosophy and Political Theology (Bloomington: Indiana University Press, 2015): 40.

46 Kolb, Martin Luther, 55-56; Lohse, Martin Luther's Theology: Its Historical and Systematic Development (Minneapolis: Fortress Press, 2011): 36.

47 Lohse, Martin Luther's Theology, 70; McGrath, Luther's Theology of the Cross, $123,149,155,200-202$.

48 Kolb, Martin Luther, 61.

49 W. Packull, 'Luther and Medieval Mysticism in the Context of Recent Historiography', Renaissance and Reformation 6.2 (1982): 81.

50 McGrath, Luther's Theology of the Cross, 202.

51 Gillespie, The Theological Origins of Modernity, 107-108.

52 Gillespie, The Theological Origins of Modernity, 107-108; Packull, Luther and Medieval Mysticism, 82. Staupitz however, focused on the righteousness of Christ 
development in his Preface to his Written Works (1545), the doctrine of alien righteousness granted forensically through grace became his alternative to the nominalists' notion of the justice of God.

\section{8. 'Theologia crucis' as Opposed to the 'theologia gloriae'}

As we have observed, Luther's thought is marked by various contrasts, one of which is the theology of the Cross in the face of its opposite, the theology of glory. This distinction is related to the contrast between the paradigms of faith and reason. However, not all of Luther's distinctions arise from irreconcilable opposites, but rather due to paradox. Writes Tracy, 'Luther's notion of dialectic ... is structured as a conflict of opposites that not only clash but imply and need each other.' ${ }^{53}$ The theology of glory is recognised by its practice of works-righteousness and its attempt to domesticate the divine, reducing the creator to the level of human striving and philosophical formulations. Thus, seeking God outside of the Cross will only result in an encounter with the 'hidden God' of judgement. ${ }^{54}$ Anticipating the thought of Barth, in the enigmatic Cross-event, God remains simultaneously hidden and revealed. Only in Christ and his Cross do we truly encounter the God of grace. ${ }^{55}$ Moreover, following Paul, Luther also presents the theology of the Cross as a challenge to the intellectual autonomy of the subject as, paradoxically, its power can only be truly experienced through repentance, the denial of the self, and the exercising of faith. As such, the believer is not 'changed' from within, but from without, through the Spirit. This means that for Luther (although foolishness to those who are perishing) the Cross nevertheless demands the re-evaluation of all theological values. ${ }^{56}$

which would work within the believer, whereas Luther would come to support the passive righteousness of Christ granted to the Christian. Packull, Luther and Medieval Mysticism, 82-83. See also the helpful discussion in S. E. Ozment, "Homo Viator": Luther and Late Medieval Theology', The Harvard Theological Review 62 (1969): 275-87.

53 Tracy, Martin Luther's Deus Theologicus, 109.

54 Lohse, Martin Luther's Theology, 38.

55 Ebeling, Luther, 80, 121, 228.

56 H.-M. Barth, The Theology of Martin Luther: A Critical Assessment (Minneapolis: Fortress, 2012): 81. According to scholars such as Rudolf Malter and Mjaaland, Luther's denial of the self has philosophical consequences as profound as those of Descartes' cogito. Here Mjaaland, The Hidden God, 116, quotes Malter: 'That human 
In the Cross, God appears as 'life' under its opposite: death, suffering, and 'nothingness', even 'non-being'. Salvation as a 'negative essential' manifests itself in that very event which is the 'negation' of all life or that which according to the assumptions of the theology of glory is the converse of goodness and wisdom. ${ }^{57}$ Through faith in the Cross and in Jesus' humanity, we encounter God's presence in his absence. Here the Deus absconditus is not completely unknown, merely hidden, just as Moses, when requesting to see the 'glory' of God, was instead presented with God's behind (posteriori Dei). ${ }^{58}$ Nonetheless, for Luther, this is a noetic and not an ontological problem as it arises not from a contradiction within the being of God but from our limited understanding of the divine. ${ }^{59}$ With the Lutheran distinction between God as hidden and revealed we locate another possible precursor to Heidegger's later distinction between Being and beings. ${ }^{60}$

Descartes' seventeenth-century epistemological separation between subject and object helped inaugurate the modern epoch, particularly belief in humans' technological mastery over the world. Heidegger and other critics, however, suggested that Cartesian dualism alienates humanity from its environment. Had he lived to see it, this Cartesian spirit of independence would doubtlessly have also been problematic for Luther, who denounced the drive for human domination. As the sinner stands before the Cross, all egotism is 'destroyed'. With Lutheran thought, the believing subject, through faith, is reduced to passivity before Christ, the unique object of faith who now assumes the initiative through the Spirit. Through the surrender of faith, the believer is reconstituted before God's revelation as the Cross establishes its own theological framework for faith and thought. ${ }^{61}$ In other words, as would

reason receives its metaphysical determination from outside and yet in terms of knowledge, is by Luther formulated as justification by faith: that is the centre of the thought of the Reformation - simple and yet highly complicated, as Descartes' thought of the cogito or Kant's idea of a transcendental deduction.' R. Malter, Das reformatorische Denken (Gottingen: Vandenhoeck \& Ruprecht, 1967): 139-46.

57 Ebeling, Luther, 81, 228, 236-38.

58 McGrath, Luther's Theology of the Cross, 203; B. A. Gerrish, "To the Unknown God": Luther and Calvin on the Hiddenness of God', The Journal of Religion 53.3 (1973): 265.

59 Gerrish, "“To the Unknown God", 273.

60 Herman Philipse, Heidegger's Philosophy of Being: A Critical Interpretation (Princeton, New Jersey: Princeton University Press, 1998): 193-94.

61 McGrath, Luther's Theology of the Cross, 206-207. 
be the case with Barth, the object of faith assumes possession of the believer. ${ }^{62}$

For Luther, the divine possession of the believer is the result of his or her transformation through the Spirit and the reading of Scripture. The study of the Bible is not merely a dry, rational interpretative process. On the contrary, an authentic openness to the living Word is mandatory. ${ }^{63}$ This aspect of Luther's epistemology is largely lost by postmodern readings of the reformer.

Finally, the theology of the Cross demands the destruction (destruuntur, destructus) of the Old Adam and his good works. ${ }^{64}$ Mjaaland points out that Luther has two destructive gestures in mind: first, we have the negation of the inflated ego, and, second, the destruction of the 'speculative metaphysics of scholastic theology'. ${ }^{65}$

\section{Martin Heidegger}

Heidegger, one of the key philosophers of the twentieth century, has exercised great influence on current discussions regarding God, and it was primarily through Heidegger that certain elements of Lutheranism have been re-appropriated in contemporary, post-metaphysical models of the Divine.

62 For a study of Barth's Protestant alternative to Barth's critique of ontotheology, see T. Stanley, Protestant Metaphysics After Karl Barth and Martin Heidegger (Eugene, Oregon: Cascade/Wipf \& Stock, 2010).

63 Kolb, Martin Luther, 46-47. Here, Luther's thinking is somewhat akin to monastic theology. States the reformer: 'May everyone be apprised, be he who he will - whether he has Moses on his side or whether he is totally submerged on his own righteousness - that there is no salvation or knowledge of God outside Christ. No one is approved by God unless he is marked with the grace and truth of the Son. This knowledge is concealed from reason. Even today the papists and all the others are ignorant of it ... this is why we say that it is impossible to see God by means of the Law or by reason. No one can fathom him, or climb to his heights. He is too lofty. He is seen only by those born of God, not by those born of the blood.' M. Luther, 'Sermons on the Gospel of St. John. Chapters 1-4' in J. Pelikan, ed., Luther's Works (Vol. 22; Saint Louis: Concordia Publishing House, 1957): 156.

64 Mjaaland, The Hidden God, 11.

65 Mjaaland, The Hidden God, 11. States Luther: 'Therefore, the friends of the cross say that the cross is good and works are evil, for through the cross works are destroyed and the old Adam, who is especially edified by works, is crucified. It is impossible for a person not to be puffed up by his good works unless he has first been deflated and destroyed by suffering and evil until he knows that he is worthless and that his works are not his but God's.' M. Luther, 'Heidelberg Disputation' in T. Lull, ed., Martin Luther's Basic Theological Writings (Minneapolis: Fortress Press, 1989), Thesis 21: 44. 
Caputo suggests Heidegger's relationship with theology evolved through four stages. ${ }^{66}$ Firstly, he trained for the priesthood and studied scholasticism at Freiburg University. ${ }^{67}$ His formulation of the question of being and what he would come to call 'fundamental ontology' essential to his landmark book, Being and Time - largely evolved from his early immersion in medieval thought. In the second stage (by 1919), Heidegger moved from Catholicism, and now professed a form of liberal, non-dogmatic Protestantism. He devoted himself to the New Testament and the texts of Luther, Kierkegaard, Schleiermacher, and Augustine. ${ }^{68}$ It was also at this time that he termed himself a 'Christian theologian'. ${ }^{69}$ Thirdly, by 1928, Heidegger's thought had evolved further through another distinct change. He became critical of Christianity and began to speak of the 'atheism' of philosophy. Evidently, he had come to regard himself as an atheist. ${ }^{70}$ With the fourth and final stage (from the 1930s forward), Heidegger embraced a form of philosophical mysticism more akin to neo-paganism than the approach of traditional theologies. ${ }^{71}$

66 Here following J. D. Caputo, 'Heidegger and Theology' in C. Guignon, ed., The Cambridge Companion to Heidegger (Cambridge: Cambridge University Press, 1993): $270 \mathrm{ff}$.

67 J. Richardson, Heidegger (London: Routledge, 2012): 26-27.

68 Safranski, Martin Heidegger, 107, 109-10; J. D. Caputo, Demythologising Heidegger (Indiana: Indiana University Press, 1993): 51. For Heidegger on Luther, see McGrath, The Early Heidegger; B. Crowe, Heidegger's Religious Origins (Bloomington: Indiana University Press, 2006); T. Kiesel, The Genesis of Heidegger's Being and Time (Berkeley: University of California Press, 1995); Van Buren, The Young Heidegger; D. Armitage, Heidegger's Pauline and Lutheran Roots (Basingstoke: Palgrave Macmillan, 2016).

69 Caputo, Heidegger and Theology, 272.

70 Crowe, Heidegger's Religious Origins, 16.

71 J. Macquarrie, Heidegger and Christianity (London: SCM, 1994): 99ff, 105. This view of the 'divine' is clearly articulated by Heidegger in the final Spiegel interview. See M. Heidegger, 'Only a God Can Save Us: The Spiegel Interview' (1966) in T. Sheehan, ed., Heidegger: The Man and the Thinker (London: Routledge, 2009). States Heidegger: 'Philosophy will be unable to effect any immediate change in the current state of the world. this is true not only of philosophy but of all purely human reflection and endeavor. Only a god can save us. The only possibility available to us is that by thinking and poeticizing we prepare a readiness for the appearance of a god, or for the absence of a god in (our) decline, in so far as in view of the absent god we are in a state of decline.' Heidegger, 'Only a God Can Save Us', 57, as quoted by Stanley, Protestant Metaphysics, 236. 


\section{The Question of Being (Die Seinsfrage) and the Ontological Difference}

Through his career, Heidegger is known for his preoccupation with the question of the meaning of 'being'. ${ }^{72}$ Although this expression was only fully conceptualised by the period of Being and Time (1927), its roots reach back to his earlier engagement with Christian theology and Luther himself.

As Kahn points out, grammatically, 'being' can refer to 'to be', as a verb or participle, or it can be used in the predicative sense of ' $X$ is $Y$ '. As a noun, we might refer to the 'being' of something in particular: its essence or its fundamental nature. Finally, 'being' can be considered from the perspective of being either potency or in act. ${ }^{73}$ Heidegger's innovation was to insist that the consideration of 'being' is actually the most primordial philosophical question, despite the fact that it had become the most neglected of modern philosophy. ${ }^{74}$ For him, traditional metaphysics is characterised by the 'forgetfulness of being' (Seinsvergessenheit). ${ }^{75} \mathrm{On}$ the basis of this innovative claim, Heidegger then redefined being in a manner which moved significantly beyond the Aristotelian tradition, as to his way of thinking 'being' is not a universal, nor does it even refer to a specific 'being'. ${ }^{76}$

To understand what Heidegger means by being, we need to refer to his notion of the ontological difference between being and beings

72 Richardson, Heidegger, 15; T. Sadler, Heidegger and Aristotle: The Question of Being (London: The Athlone Press, 1996): 1.

73 C. Kahn, 'The Greek Verb "To Be" and the Concept of Being' in Essays on Being (Oxford: Oxford University Press, 2009): 21. See also M. Inwood, A Heidegger Dictionary (Oxford: Blackwell, 1999): 26. Gilson also discusses the difficulty of defining 'being': E. Gilson, Being and Some Philosophers (Toronto: Pontifical Institute of Medieval Studies, 1949): 2-3. Showing a certain indebtedness to Augustine and Henry of Ghent, Gilson believes that 'Being is the first principle of human knowledge.' This suggests a univocal view of being.

74 M. Heidegger, Being and Time, trans from the German by J. Macquarrie and E. Robinson (Oxford: Blackwell, 1962): 21, 'The Necessity, Structure and Priority of the Question of Being'.

75 Sadler, Heidegger and Aristotle, 38.

76 'In the question which we are to work out, what is asked about is Being - that which determines entities as entities, that on the basis of which entities are already understood ... the Being of entities "is" not itself an entity.' Heidegger, Being and Time, 'The Formal Structure of the Question of Being', 24. 
introduced in 1927. It is to this paradoxical distinction that we can trace the origins of much postmodern theology. ${ }^{77}$

For Heidegger, the question of being has been forgotten due to the West's focus on particular entities, or 'beings' (das Seiende), rather than being (das Sein) itself. Philosophers have succumbed to this error in various ways. ${ }^{78}$ For example, being has been viewed as 'God', (Heidegger calls this ontotheology) or as some form of 'universal', abstracted from beings. It has also been regarded as a property of entities. Somewhat reminiscent of Scotus' own approach to univocity, Heidegger insists that being's identity and significance must be understood as 'primordial' or prior to all other concepts. ${ }^{79}$ Indeed, attending to the question of being is prior even to all others asked by the sciences, including theology. ${ }^{80}$

Respecting the accessibility of truth, Heidegger points to the fact that modernity has always pursued some form of fundamentalism, whether in the shape of 'God', 'logic', or the a priori structures of the human mind (as in the case of Kant). Such grounds have made the sciences possible. For Heidegger, however, there are no transcendental or any other 'grounds' on to which to bed the rules of science, propositional truth, or logic. ${ }^{81}$ The grounds are groundless. ${ }^{82}$ This is

77 'Out of the holy sway of the godhead, the god appears in his presence or withdraws into his concealment ...' M. Heidegger, 'Building, Dwelling, Thinking' in D. F. Krell, ed., Martin Heidegger: Basic Writings (London: Routledge, 1996): 351-52.

78 Following Inwood, A Heidegger Dictionary, 47.

79 For more details, see P. Tonner, Heidegger, Metaphysics and the Univocity of Being (Continuum Studies in Continental Philosophy; London: Continuum, 2010).

80 Inwood, A Heidegger Dictionary, 47, 149-50. See also Heidegger, Being and Time, 29-31. Writes Heidegger further: 'For example, anyone for whom the Bible is divine revelation and truth already has the answer to the question "Why are there beings at all instead of nothing?" before it is even asked: beings, with the exception of God Himself, are created by him. God Himself "is" as the uncreated Creator. One who holds onto such faith as a basis can, perhaps emulate and participate in the asking of our question in a certain way, but he cannot authentically question without giving himself up as a believer, with all the consequences of this step. He can only act "as if". On the other hand, if such faith does not continually expose itself to the possibility of unfaith, it is not faith but a convenience. It becomes an agreement with oneself to adhere in the future to a doctrine as something that has somehow been handed down ...' M. Heidegger, Introduction to Metaphysics, trans from the German by G. Fried and R. Polt (New Haven: Yale University Press, 2000): 7-8.

81 'The idea of logic itself disintegrates into the turbulence of a more original questioning.' Heidegger, What is Metaphysics?, 105.

82 L. Braver, Groundless Grounds: A Study of Wittgenstein and Heidegger (Massachusetts: MIT Press, 2012): 11. States Heidegger: 'And-yet Being offers us no ground and no basis as beings do to which we can turn, on which we can build, and to which we can cling. Being is the rejection of the role of such grounding; it renounces 
unquestionably a break with modernism and, indeed, all medieval philosophy. As one of the key progenitors of the postmodern outlook, Heidegger situates being outside the realm of conceptual thought. 'Being' is prior to beings, even negative thoughts of 'nothingness' ${ }^{83}$ As such, we can regard being as 'nothing' or 'no-thing'. ${ }^{84}$

Metaphorically speaking, being is the 'light' which enables us to perceive beings as 'unconcealment', as the illumination (Lichtung) in a forest clearing: being enables beings to 'emerge' for us as humans as 'truth' (aletheia). It is evident that although Heidegger excoriates cognitive-based, correspondence theories of truth, nevertheless, being as groundless (ab-grund) allows all traditional models of 'truth' to emerge for humanity in the first place. ${ }^{85}$ Beginning with Aristotle and Plato, the West's focus on beings resulted in the forgetfulness of being and how it originally gave rise to the emergence of beings at the beginnings of the history of thought.

Borrowing from the New Testament and the Lutheran view of the revelation of the hidden God, Heidegger discusses being as that which paradoxically reveals beings, but nevertheless hides itself in the process. Being is most 'evidenced' in its absence at that moment of the disclosedness (ereignis) of beings. ${ }^{86}$

all grounding, is abysmal.' M. Heidegger, Nietzsche Vol. IV. Nihilism, trans F. A. Capuzzi (New York: Harper \& Row, 1987). This text was drawn to my attention by J. K. Lyon, Paul Celan and Martin Heidegger: An Unresolved Conversation, 1951-1970 (Baltimore: Johns Hopkins University Press, 2006): 42.

83 Heidegger, What is Metaphysics?, 98.

84 Heidegger, What is Metaphysics?, 108.

85 M. Heidegger, 'The End of Philosophy and the Task of Thinking' in Krell, ed., Martin Heidegger, 441-44.

86 In the earlier Heidegger of Being and Time (1927) there is a close relationship between being and human beings in that being exclusively 'discloses' itself to human beings according to a specific set of ' $a$ priori' but temporal conditions. Here we encounter not only Heidegger's indebtedness to Kant but also Husserl's phenomenology. However, unlike Husserl, Heidegger does not argue for 'being' presenting itself to humans according to some form of transcendental, theoretical stance, whereby we must 'bracket' out everyday human experience according to the Cartesian sense of the thinking subject over against objects. For Heidegger, Husserl fell into this trap. On the contrary, the human being always finds himself/herself in a world of everyday objects, tools, and equipment. Contrary to Descartes, the human being is always 'there' in the world. Thus, all questioning of being needs to be conceptualised from this starting point, i.e., human being in the world as 'Dasein' (or 'being-there'). Being only manifests itself to Dasein in its temporality and it is this temporal, factical horizon which forms the backdrop against which the issue of being is to be resolved. In this regard, see also Heidegger, What is Metaphysics?, 94. 


\section{The Young Heidegger, Paul, and Luther}

We have considered how, in moving away from scholasticism as a young scholar, the topic of 'being' became Heidegger's new entry point into philosophy, one which would circumvent the dry metaphysical theories of the scholastics and the neo-Kantians. Indeed, the panoply of quasi-religious lexical terms appearing later in Being and Time was partly derived from the Protestantism of Luther and Kierkegaard. ${ }^{87}$ Studying Luther shortly after the First World War (1919-1923) whilst at Freiburg, Heidegger was drawn to themes in Luther's theology, one of which was the call to return to an authentic New Testament Christian experience, later obscured by Hellenism and then scholasticism. ${ }^{88}$ It would appear that his casting of the being question as a movement away from the 'theoretical worldview' and towards a return to authentic 'life-experience' is partly indebted to a reading of Paul, Augustine, Luther, and others. ${ }^{89}$ When it comes to the meaning of human existence, these individuals led Heidegger to the conviction that the 'life-forms' of early Christianity enjoyed a certain pre-theoretical authenticity which was lost when Greek thought was imported into the faith. Furthermore, Heidegger believed that Luther perceived this too, and this fundamental, primal Christian experience

87 H. Philipse, Heidegger's Philosophy of Being (Princeton, New Jersey: Princeton University Press, 1998): 175, 176, 180ff. Here we can include ideas such as 'falling', 'anxiety', the 'leap', and so on.

88 Van Buren, The Young Heidegger, 159ff. See also J. Van Buren, 'Martin Heidegger, Martin Luther' in T. Kisiel and J. Van Buren, eds, Reading Heidegger from the Start: Essays in his Earliest Thought (New York: State University of New York Press, 1994): 160. Writes Heidegger, 'It is a decrease of authentic understanding if God is grasped primarily as an object of speculation. That can be realized only if one carries out the explication of the conceptual connections. This, however, has never been attempted, because Greek philosophy penetrated into Christianity. Only Luther made an advance in this direction, and from this his hatred of Aristotle can be explained.' M. Heidegger, 'Phenomenological Explication of the First Letter to the Thessalonians' in Phenomenology of Religious Life, trans. M. Fritsch and J. A. GosettiFerencei (Indianapolis: Indiana University Press, 1995): 67. Heidegger's reading of these authors is typical of much of his hermeneutic methodology; he shows little regard for original authorial intention or the historical-critical method as he reads texts as subordinate to his own ontological project. In this sense, his is an 'antiphilosophical' project. See J. Van Buren,'The Earliest Heidegger: A New Field of Research' in H. Dreyfus and M. Wrathall, eds, A Companion to Heidegger (Oxford: Blackwell, 2007): 20. As a matter of interest, some have maintained that Heidegger actually began to read Luther as early as 1909 .

89 Here we could also mention the influence of Dilthey's 'historical life hermeneutics' on Heidegger's thought. 
(Urchristentum) became an important impetus for his own postmetaphysical project.

Heidegger also engaged in phenomenological readings of Paul's letter to the Galatians, the second letter to the Corinthians, and the the two letters to the Thessalonians. ${ }^{90}$ The Apostle also enabled him to reappropriate the principle of a hidden God (Deus absconditus) who escapes all dialectic, scholastic formulations. ${ }^{91}$ Moreover, other Pauline themes also resonated with Heidegger, particularly the experience of anxiety in the face of an uncertain future. In facing the Day of the Lord, Paul's congregations found themselves in an existential situation bathed in uncertainty. ${ }^{92}$ Heidegger also notes a particular temporal mood in the Apostle who summons his readers to live according to a radically temporal faith, one embracing 'kairological' time as opposed to the unauthentic 'chronological' or metaphysical time of later Greekbased theologies. ${ }^{93}$ These Pauline ideas reappear in Being and Time, but reworked into a secular, existential framework.

Heidegger was also convinced that Luther's theology of the Cross and his 'destruction' of the scholastic tradition shared some of Paul's priorities regarding the deconstruction of the God of the philosophers, but this appreciation, however, did not turn Heidegger into a Lutheran. ${ }^{94}$

90 See 'Phenomenological Explication of Concrete Religious Phenomena in Connection with the Letters of Paul', Chapter One: 'Phenomenological Interpretation of the Letters to the Galatians'; Chapter Three: 'Phenomenological Explication of the First Letter to the Thessalonians'; Chapter Four, The Second Letter to the Thessalonians' in Heidegger, Phenomenology of Religious Life.

91 Van Buren, Martin Heidegger, Martin Luther, 161-62.

92 'Paul lives in a peculiar distress, one that is, as apostle, his own, in expectation of the second coming of the Lord. This distress articulates the authentic situation of Paul. It determines each moment of his life. He is constantly beset by a suffering, despite his joy as apostle.' Heidegger, 'Phenomenological Explication of the First Letter to the Thessalonians', 67-69.

93 In 1921, Heidegger makes similar claims respecting the thought of Augustine. Whilst in the Confessions we can discern the vestiges of an authentic faith, this is lost when Augustine later subjects faith to neoplatonic categories of 'presence'.

94 'Already in the strongly natural-scientific, naturalistic theoretical metaphysics of being of Aristotle and its radical elimination and misrecognition of the problem of value in Plato, which is renewed in medieval Scholasticism, the predominance of the theoretical is already potentially present, so that Scholasticism, within the totality of the medieval Christian world of experience, severely endangered precisely the immediacy of religious life, and forgot religion in favor of theology and dogma. And already in the early days of Christianity, these dogmata exercised a theorizing, dogmapromoting influence on the institutions and statutes of church law. An appearance such as mysticism is to be understood as an elementary counter-movement.' M. Heidegger, 
With Luther, however, the noetic proclivities of transgression prevent the sinner from knowing God exclusively through reason, whereas Heidegger had no place for belief in a rebellious humanity accountable to a personal God and deserving of judgement. ${ }^{95}$ Alternatively, in Being and Time, the principle of ' $\sin$ ' is reconceived as a form of 'social inauthenticity' or 'fallenness' evidenced by a herd, everyday mentality (Heidegger speaks of 'das man'/'the they') which fails to embrace the true meaning of human temporality. ${ }^{96}$ For Luther, the alternative to the theology of glory lay in the renewed study of Scripture, the flight to the Cross of Jesus, and, of course, repentance. Heidegger's alternative to speculative theologies of glory was to retreat from metaphysics into an atheistic, hermeneutic philosophy of 'authentic existence', not personal faith in Christ. Luther's existential crisis (Existenzbegriff) brings him to the Word and to faith, whereas Heidegger's leads to an anti-metaphysical retreat into the phenomenological analysis of 'factical' life.

\section{Conclusions: Heidegger, Luther, and the Limits of Post-Metaphysical Views of God}

Since the age of Tertullian, the debate concerning the extent to which philosophy should be incorporated into theology continues, even if 500 years after the Reformation the metaphysical landscape has radically changed.

We have considered how Heidegger's metaphysical reading of Luther led to certain postmodern views of God. Although somewhat of an overstatement, there is truth in Armitage's assertion that 'since Heidegger's disdain for onto-theology is rooted in Luther, essentially all postmodern theological thinking is fundamentally Lutheran' ${ }^{97}$

\footnotetext{
'The Philosophical Foundations of Medieval Mysticism' in Phenomenology of Religious Life, 238. Heidegger discussed the Heidelberg Disputation his 1920/1921 seminar on 'Augustinus und der Neuplatonismus'. McGrath, The Early Heidegger and Medieval Philosophy, 158. Luther's seminar on Augustine is available in Heidegger's Phenomenology of Religious Life. This volume includes Heidegger's early lectures entitled 'Introduction to the Phenomenology of Religion', 'Augustine and Neoplatonism', and 'The Philosophical Foundations of Medieval Mysticism'.

95 McGrath, The Early Heidegger and Medieval Philosophy, 155, 158-59.

96 Heidegger, Being and Time, $220 \mathrm{ff}$.

97 Armitage, Heidegger's Pauline and Lutheran Roots, 153.
} 
From the 1960s, Luther's Deus absconditus played a background role in the establishment of continental philosophy's anti-realism, employed as a means of overcoming the metaphysics of the Cartesian cogito. Remarkably, this has led to the inclusion of religious terms in current phenomenological philosophies of post-subjectivity. In a report to the French government in 1991, Dominique Janicaud demonstrated how philosophy in France had been appropriated by new theologies of God 'without Being'. ${ }^{98}$ Clearly, Luther's and Heidegger's legacies are evident here.

These thinkers range from Vattimo, Derrida, Levinas, and Marion to Badiou, Nancy, and Meillassoux, and radical orthodoxy. ${ }^{99}$ However, in our view, when Luther's critique of metaphysics is emptied of all its biblical substance in order to be recast as a nebulous conception of

98 J.- L. Marion, God without Being, trans T. A. Carlson (Chicago: University of Chicago Press, 1995). See also B. E. Benson, 'Continental Philosophy of Religion' in R. Braidotti, ed., The History of Continental Philosophy: Vol 7. After Poststructuralism: Transitions and Transformations (Durham: Acumen, 2010); D. Janicaud, 'The Theological Turn of French Phenomenology', trans. B. G. Prusak in D. Janicaud et al., eds, Phenomenology and the "Theological Turn": The French Debate (New York: Fordham University Press, 2000). This new intellectual current became a quest to think God after God. Derrida's deconstruction (also derived from Luther's destruktion) as an example, whilst not entirely rejecting God-talk, questions the viability of traditional Christian doctrine due to the fact that as soon as we regard God as 'present' we fall back into ontotheology or metaphysics. Alternatively, deconstruction through its heterogeneous view of différance only allows for a God, or a 'messianism-to-come', a radical eschatological deity who in order to escape the metaphysics of parousia can never be here or present. Luther introduced the radical notion of the gift of the wholly other (tout autre), or God's grace in its transcendence offered to undeserving sinners as a gift. Derrida employs and radicalises this Lutheran economics of gift-exchange as a metaphor of the deconstructive approach to religion. However, for Derrida, the 'gift' is not propositional revelation or salvation offered by a benevolent creator, or even faith in Christ. Instead it is a semi-mystical attitude of 'openness' towards a future hope, an indistinct impossible possibility residing outside all human discourse and thought. This is 'religion without religion'. Furthermore, due to its very gesture, the granting of a true gift can never truly take place due to the fact that once given it then creates in the recipient the obligation of reciprocation, nullifying the giving in the first place. The gift is perpetually offered but as true giving must exceed metaphysical closure or the singularity of a specific event, there is no finality in its granting. J. Derrida, The Gift of Death, trans. D. Wills (Chicago: Chicago University Press, 1995): 49, 55-58. See also the study of J. Caputo, The Prayers and Tears of Jacques Derrida: Religion without Religion (Bloomington and Indianapolis: Indiana University Press, 1997). This deeply paradoxical opacity in Derrida and others has led Gutting to characterise French Continental philosophy since the 1960s as 'thinking the impossible'. G. Gutting, Thinking the Impossible: French Philosophy Since 1960 (Oxford: Oxford University Press, 2011): 184-85.

99 See the study of C. Watkin, Difficult Atheism: Post-Theological Thinking in Alain Badiou, Jean-Luc Nancy and Quentin Meillassoux (Edinburgh: Edinburgh University Press, 2011). 
'being' or 'event', this anti-metaphysical interpretative approach banishes the reformer from his historical context and tarnishes his legacy. To rectify this problem, the appropriation of Lutheran principles in contemporary philosophy needs to be reconsidered on their own historical terms.

Certainly, there is much to be mined from Luther for philosophy, but I suspect that the historical Luther would have concurred with the view that the dismissal of metaphysics amounts to the undermining of rationality itself, and this is both untenable and contrary to the biblical doctrine of the creation. ${ }^{100}$ There can be no viable theology in service of historical orthodoxy without the use of metaphysical language, and Luther's own views would concur with this. ${ }^{101}$

Ironically, the attempts of Heidegger and his successors to redirect the idea of Luther's transcendent God (Deus absconditus) in an antimetaphysical direction in order to overcome the metaphysics of modernism produces its own problems. In rejecting biblical revelation instead of relieving us from the tenets of modernism, anti-metaphysical or post-metaphysical theologies return us to the anti-supernatural presuppositions of the Enlightenment (even if in post-metaphysical theologies these are reformulated in a mystical guise). Subsequently, and despite claims to be 'open' towards the divine, this actually results in the collapse of divine transcendence. Paradoxically, with the excessive stress placed on transcendence, the post-metaphysical deity actually 'loses' its transcendence in that it becomes subordinated to the priorities of culture, that is, a projection of the human condition of our secular, liberal age. ${ }^{102}$ We are reminded of Barth's critique of

100 Armitage, Heidegger's Pauline and Lutheran Roots, 157. Kant also makes a helpful observation: 'For human reason, without being moved merely by the idle desire for extent and variety of knowledge, proceeds impetuously, driven on by an inward need, to questions such as cannot be answered by any empirical employment of reason, or by principles thence derived. Thus in all men, as soon as their reason has become ripe for speculation, there has always existed and will always continue to exist some kind of metaphysics.' I. Kant, Critique of Pure Reason, trans N. K. Smith (London: Macmillan, 1964), B21: 56.

${ }^{101}$ For example, here we can refer to Luther's use of philosophical language in his doctrine of the Trinity. See C. Helmer, 'God from Eternity: Luther's Trinitarian Understanding', The Harvard Theological Review 96.2 (2003): 136.

102 Consider McCaffrey's description of Vattimo's attempt to describe the role of religion: 'The return of religion is not a new claim to any ultimate religious truth. It is not to be construed as a religious "leap of faith" in the mystical or devotional sense, nor is it designed to undermine philosophical atheism ... The return of religion is not a return to a new transcendence, nor does it seek verification and authenticity in "normative" church. Rather the return of religion is the capacity to think of Being as an 
Schleiermacher, whose theology of human consciousness manifested the same problem: the intrusion of liberal culture into theology.

Critics have accused Luther's idea of the Deus absconditus as a tendency towards fideism. Certainly, one does locate an inclination in this direction. In his defence, however, when discussing God's hiddenness, Luther merely intends to stress the absence of God in the face of scholastic pretensions and human arrogance. On the other hand, Nietzsche, Heidegger, and their successors speak in different ways of the death of the Christian God. ${ }^{103}$

Certainly, Luther never wrote an extended work of theology in which he discussed his antithetical views in a systematic manner. His strong language therefore needs to be placed into the context of his temperament and, of course, his conflict with medieval theology and the papacy (characteristic of the early Reformation). Here, interestingly, we can draw a contrast between Luther and Calvin. Although Calvin's theology also holds a place for the hiddenness of God, this does not perform as prominent a role as it did in Luther. ${ }^{104}$ And, of course, in seeking to fully understand Luther, we need to balance the transcendence of God with the roles fulfilled by his Christology and doctrine of Scripture; here, God does make himself known. Failing to do this distorts his historical legacy and results in misreadings of his work. Considering his life and convictions, undoubtedly Luther would have rejected contemporary nihilist interpretations of his theology, and this means we need to move beyond Heideggerian readings of the reformer. ${ }^{105}$

However, positively speaking, the Lutheran heritage does remind us that all theological language about God will, at points, be unavoidably paradoxical. ${ }^{106}$ Yet whilst theology should adopt a healthy appreciation

Event not as an objective structure, but to discover God "handed over in historically changing forms ... to the continuing reinterpretation of the community of believers".' McCaffrey, The Return of Religion in France, 98.

${ }^{103}$ F. Nietzsche, The Gay Science, trans. J. Nauckhoff (Cambridge Texts in the History of Philosophy; Cambridge: Cambridge University Press, 2001): 119-20.

104 Gerrish, "“To the Unknown God"', 281-86.

105 Stanley, Protestant Metaphysics, 238-39. Stanley writes: 'Rather, by returning to the Protestant theology which influenced Heidegger's understanding of ontotheology in the first place, we can uncover alternative strategies and lost insights into the ontotheological problem ...' Stanley, Protestant Metaphysics, 239.

106 Of course, with Luther as a Christian theologian, this paradox is resolved at the eschaton where the power of sin is finally eradicated and our knowledge of God, whilst still creaturely, is nevertheless perfected. On the other hand, the atheistic, paradoxical element in Heidegger's thought ultimately never reaches any resolution. As Wolfe 
of God's transcendence, this should not lead to such contrasts between God and the creation that theological knowledge expressed in the vocabulary of being is no longer possible. The principle of the incarnation holds out the promise that whilst God is ultimately beyond being, he nevertheless generously chooses to accommodate himself to theological language within the realm of being. The Heideggerian reading of Luther, therefore, leads to a dead end.

Finally, we should also acknowledge Luther's warnings respecting the limits of metaphysics, as ultimately the subject of our faith will always precede and transcend philosophical formulation. The reformer summons the church to engage in philosophy circumspectly and in the light of divine revelation, as overreliance on pagan conceptual categories can obscure those aspects of the gospel which surpass human comprehension. Reformation theology should not subordinate itself to any specific philosophical school or faction in the service of God. On the contrary, it should only utilise those germane metaphysical models which allow it to most effectively explicate the biblical message.

points out, 'Heidegger's eschatology, by positing death or Nothing rather than eternal life or God as the horizon of an eschatological (and therefore authentic) existence, itself runs into problems that may best be explained as consequences of attempting to eradicate the religious foundations of an irreducibly religious concept.' J. Wolfe, Heidegger's Eschatology: Theological Horizons in Martin Heidegger's Early Work (Oxford: Oxford University Press, 2013): 5. 